Ann. Génét. Sél. anim., I975, ry (4), 357-364.

\title{
EFFECT OF GENES AFFECTING TAN COLOUR ON PRODUCTIVITY IN ICELANDIC SHEEP
}

\author{
S. ADALSTEINSSON \\ The Agricultural Research Institute, \\ Keldnaholt v/Vesturlandsveg, Reykjavik (Iceland)
}

SUMMARY

An account is given of the effect, within the Icelandic Sheep breed, of pelt class of sire and pelt class of daughter on lambing records of 1270 daughters at I, 2 and 3 years of age and on carcass score of 1023 daughters at the ages 2 and 3 years. Daughters of $14 \mathrm{I}$ sires were included in the study. The pelt classes were : A, pure white lustrous, long and even fleece, B, pure white with lower quality fleece, $\mathrm{C}$, white with $\tan$ colour on outskirts of fleece, and D, white with tan fibres in the fleece.

Sires in pelt classes $A$ and $B$ had heavier weaning weight of daughters than sires in other pelt classes. Daughters in pelt classes A and B were lighter at weaning than those in other pelt classes due to lowered selection intensity for weaning weight.

The pelt class of sire did not significantly affect any of the production traits.

No effect of pelt class of sire or pelt class of daughter on ewe fertility could be demonstrated.

Daughters in pelt classes A and B had lower score for carcass production than daughters in pelt classes $C$ and $D$.

\section{INTRODUCTION}

The research work to be described here has been aimed at improving the Icelandic sheep breed with respect to pelt colour and pelt quality of lambs at slaughter and wool colour and quality of adult sheep. The sheep referred to in the present study have been either white or tan coloured.

A description of the origin of the Icelandic sheep breed and its characteristics has been given by ADALSTEINSSON (I966, I970).

The fleece of the white or $\tan$ Icelandic sheep is doublecoated, with very fine, short and soft undercoat and long, rather coarse outercoat. In addition to the undercoat and outercoat fibres, white and red (tan) kemp fibres also occur (ADALSTEINSSON, I975).

It has been shown by IAUVERGNE (I975) that the tan colour appears in sheep 
which carry the gene $A^{w n}$, and the tan colour is converted to pure white colour in sheep which are homozygous for the gene for piebaldness $S^{b}$.

The investigations to be reported on here have been aimed at two main aspects. The first of these was the occurrence and inheritance of tan fibres in the pelt of lambs at slaughter, and the other aspect has been the connection between the occurrence of tan colour and other production caracteristics of economic importance such as ewe fecundity and lamb weights. Information on the above aspects has been obtained during the process of selection against tan colour.

In a previous paper (ADALSTEINSSON, I975) a review has been given of several investigations regarding the occurrence and inheritance of tan fibres in the fleece, and of some preliminary investigations regarding the connection between tan colour and production characteristics. The main conclusion drawn from those earlier investigations was that the heritability of the amount of tan colour was high or around $\mathbf{0 . 5}$ (ADALSTEINSSON, I97I $b$ ), and no definite connection had been found between the occurrence of tan colour and production characteristics.

In the present paper the relationship between pelt quality of autumn lambs and ewe productivity, in terms of number of lambs and weight of lambs, is investigated further.

\section{MATERIAI, AND METHODS}

The data on which the present investigation is based were collected on four State farms in Iceland during the period I965-1974. The sheep flocks and husbandry practices have been described earlier (ADALsteinsson, I97 I $b$ ).

All white and tan female lambs kept for breeding during the period 1965 to 197 I and which had been on record up to and including the age of $3 \mathrm{I} / 2$ years were included in the analysis.

The female lambs had all been scored for pelt quality at weaning time into one of the four classes shown in table $\mathrm{r}$.

TABLE I

Description of pelt classes of lambs at weaning

Classification des fourrures des agneaux au sevrage

\begin{tabular}{c|c}
\hline \hline Pelt class & Description \\
A & $\begin{array}{l}\text { No tan fibres, outer coat long, wavy, even and lustrous. } \\
\text { No tan fibres, outer coat uneven or short or whitout } \\
\text { lustre, or white kemp in the coat. } \\
\text { Tan fibres occuring on extremities and outskirts of } \\
\text { fleece, but main part of fleece white. } \\
\text { Tan fibres occuring on body. }\end{array}$ \\
\hline
\end{tabular}

Records were also available on the age of the selected female lambs in days on Ist October and on their weaning weight, which was taken around that date. Also available was the age of the dam, the identification number of the sire and the sire's pelt class, and finally whether the 
lamb had been born as a single ( $\mathrm{x}$ ), twin (2) or a triplet (3), and whether it had been reared as a single ( 1 ), twin (2) or occasionally as a triplet (3).

The data on each female lamb up to and including weaning were combined with the production records of the same animals in later life.

The production records included number of lambs born at ewe ages $\mathrm{r}, 2$ and 3 years and scores for carcass weight of weaned lambs at ewe ages 2 I/2 and $3 r / 2$ years. All ewes which weaned one or more lambs were given a score for carcass weight production according to the system described earlier (ADALsteinsson, I971 $a$ ). The average score for all ewes on the farm in a given year is 5.0 , and the theoretical standard deviation 1.43 which should ascertain that 99,96 per cent of the scores lie between the values o and ro. The ewes which reared no lamb were not given any production score.

A rearing score of $I$ was given to ewes which reared a lamb, and obtained a lamb weight score, while ewes which reared no lamb and ewes with abnormal records were given a rearing score of $o$.

The analysis was carried out by the least squares technique assuming all effects to be fixed.

The effects which were taken into account and for which least squares constants were fitted simultaneously will be described in connection with the results from the various analyses.

The least squares analysis was carried out on an IBM $37 \% /$ I 35 computer in Reykjavík using the LSMLMM programme by HARVEY (I972).

\section{RESULTS AND DISCUSSION}

Altogether I 280 white or tan ewes selected for breeding during the years I 965 to $\mathrm{I} 97 \mathrm{I}$ were included in the analysis.

The distribution of the sires and daughters by pelt classes is given in table 2 .

TABI,E 2

Number of sires, and number of daughters per sire by sire pelt class, and number of daughters per daughter pelt class

Répartition des mâles selon leur note de fourrure avec leur nombre moyen de descendantes et répartition des filles selon leur note de fourrure

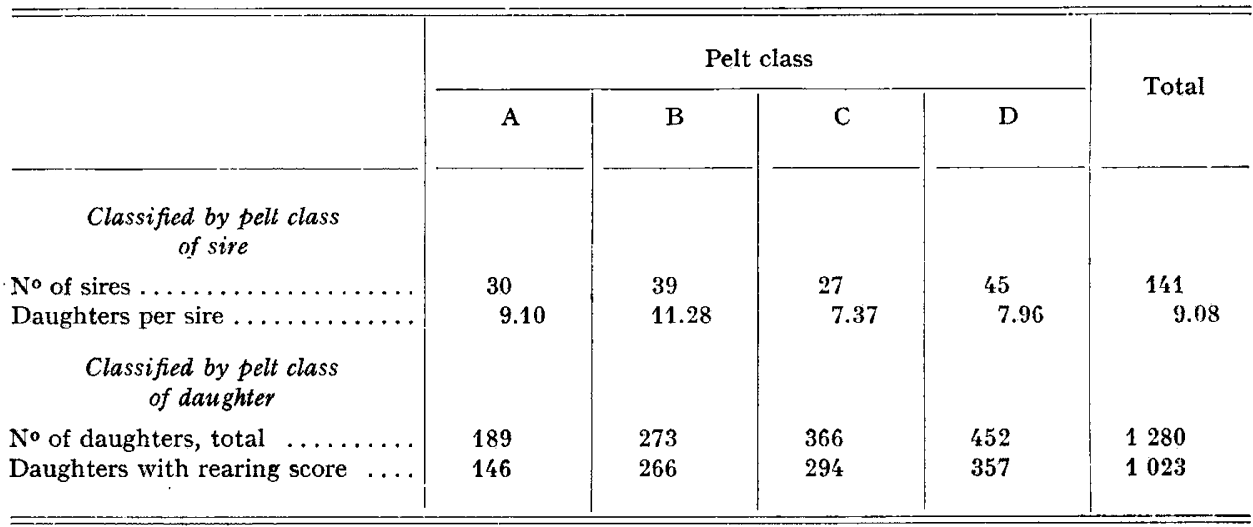

Table 3 shows selected comparisons among pelt classes for sires and daughters and their t-values, with respect to weaning weight of daughters. The records have been corrected simultaneously for farm, year of birth, age of dam, type of birth and rearing, and age of selected daughter in days on Ist October. 
The comparisons in table 3 show a significant difference in weaning weight of ewes between white $(A+B)$ and $\tan (C+D)$ sire groups in favour of the white sires. The opposite effect is found for pelt class of daughters, where daughters in pelt classes $A$ and $B$ are significantly lighter at weaning than daughters in the tan classes $\mathrm{C}$ and $\mathrm{D}$.

TABLE 3

Selected comparisons among pelt classes for sires and daughters with respect to weaning weight of daughters

Quelques comparaisons entre classes de fourrure pour les brebis et leurs filles quant au poids au sevrage des filles

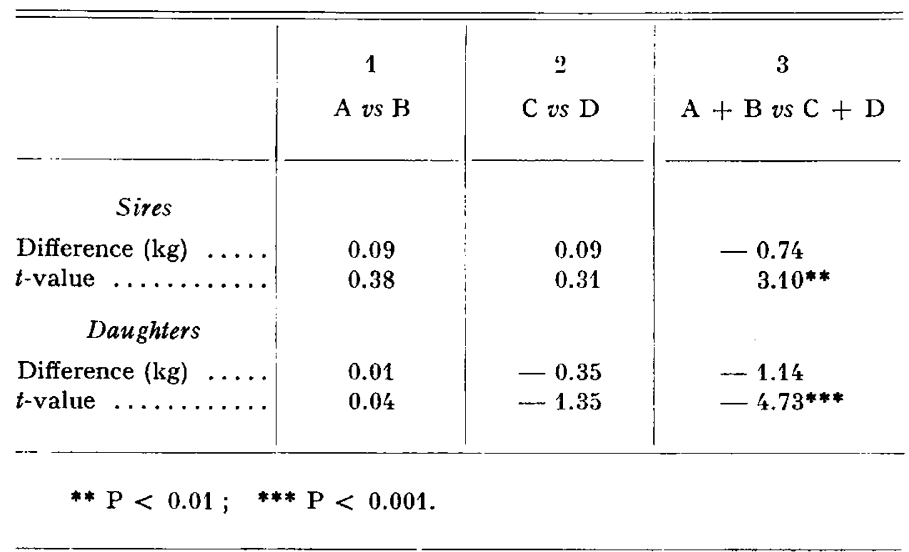

The reason for the difference between sire pelt classes could be a result of confounding of sire pelt class with time. Genetic progress in live weight might then be expected to bring about this difference.

The difference between the daughter pelt classes was to be expected, since selection against tan colour was carried out during the period, resulting in appreciably less selection intensity for live weight among the white than among the tan female lambs.

The differences in weaning weight of daughters shown in table 3 would be expected to have some effect on production ability of the ewes in later life.

A seperate analysis was therefore carried our in order to estimate the effect of weaning weight on number of lambs born per ewe on record and per ewe lambing at the ages $\mathrm{I}, 2$ and 3 years. The effect of weaning weight on rearing score (RS) of 2 year old ewes and carcass weight score (CS) of 2 and 3 year old ewes was also assessed. The regression coefficients and $\mathrm{F}$-values for the regression coefficients are shown in table 4.

The effects of farm, year of birth, age of dam, pelt class of sire, pelt class of daughter and type of birth and rearing were estimated simultaneously with the regression coefficients shown in table 4 .

As can be seen from table 4 , the weaning weight of the daughters has a significant effect on number of lambs born at I and 2 years of age, and also on carcass weight score at 2 and 3 years of age. 
On basis of the results obtained in tables 3 and 4 it was decided to use weaning weight as a regression variable in the analysis of the effect of pelt class of sires and daughters on production traits, except for rearing score of 2 year old ewes.

TABLE 4

Effect of weaning weight of daughters (x) on production traits $(\mathrm{y})$

Influence du poids au sevrage des filles (x) sur des caractères de production (y)

\begin{tabular}{c|c|c|c}
\hline \hline Trait & $\bar{y}$ & $b\left({ }^{1}\right)$ & $F\left({ }^{2}\right)$ \\
- &
\end{tabular}

A. - All ewes $(\bar{x}=36.19 \mathrm{~kg})$

\begin{tabular}{l|l|r|r}
$N^{\circ}$ of lambs, 1st year . . . & 0.17 & 0.0067 & $5.671^{*}$ \\
$N^{\circ}$ of lambs, 2nd year . . . & 1.34 & 0.0165 & $10.253^{* *}$ \\
$N^{\circ}$ of lambs, 3rd year . . . & 1.53 & -0.0002 & 0.003 \\
Rearing score, 2nd year ... & 0.86 & -0.0041 & 1.984 \\
\hline
\end{tabular}

B. - Ewes with carcass scores 2 nd and $3 r d$ year

\begin{tabular}{|c|c|c|c|}
\hline $\mathrm{N}^{\circ}$ of lambs, 1st year... & 0.17 & 0.0078 & $6.194^{*} *$ \\
\hline No of lambs, 2 nd year... & 1.45 & 0.0211 & $20.184 * * *$ \\
\hline$N^{0}$ of lambs, 3rd year .... & 1.59 & 0.0045 & 0.910 \\
\hline Carcass score 2nd year ... & 4.49 & 0.0516 & $12.947 * * *$ \\
\hline Carcass score, 3rd year ... & 5.01 & 0.0633 & 23.60 **** \\
\hline
\end{tabular}

The other effects for which constants were fitted when analysing the production traits were farm, year of birth, pelt class of sire, pelt class of daughter and type of birth and rearing of daughter.

Table 5 shows the difference in number of lambs born and rearing score for selected comparisons of pelt classes of sires and daughters.

The comparisons in table 5 show that the only significant effect of sire pelt class on the traits in table 5 is lowered number of lambs of 3 year old daughter of sires in pelt class A. As this effect is only found to be significant at one age level one is inclined to ascribe it to chance. It can at any rate not be ascribed to absence of tan colour, because the daughters of sires in pelt class $B$ of the same age are just above average.

In table 6 are shown differences in number of lambs and carcass scores for selected comparisons of pelt classes for ewes with carcass scores at 2 and 3 years of age.

The comparisons with regard to number of lambs in table 6 show much the same picture as those in table 5 , except that the deficiency of number of lambs among daughters of sires in pelt class $\mathrm{A}$ is no longer significant. 
TABLE 5

Differences in number of lambs born per daughter on record and differences in rearing score for selected pelt class comparisons

Différences dans le nombre d'agneaux nés par fille contrólée et différences dans le nombre d'agneaux élevés selon les classes de fourrure

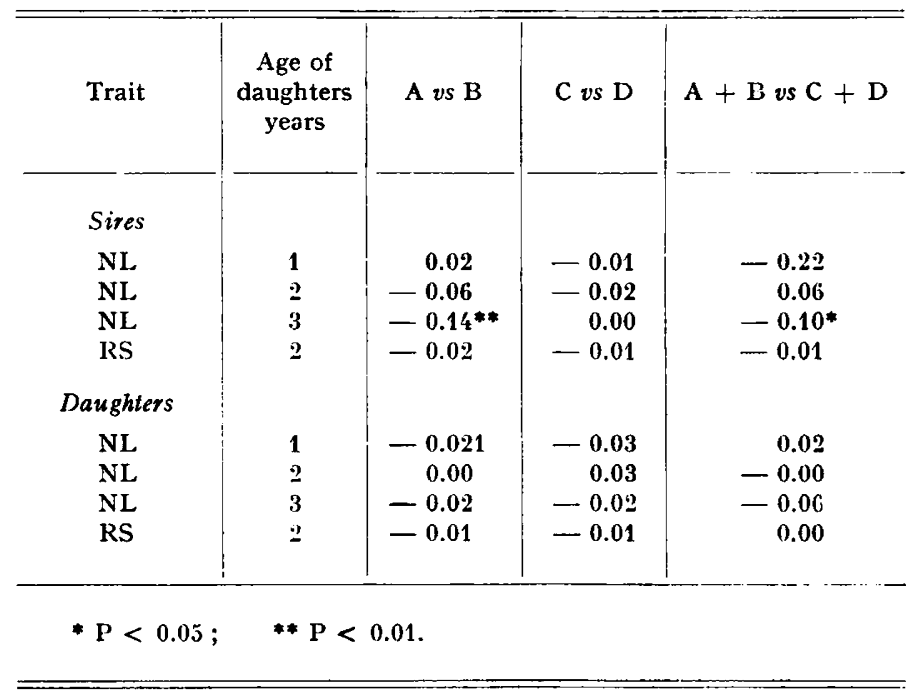

TABLE 6

Differences in number of lambs born per daughter and differences in carcass score for selected pelt class comparisons

Différences dans le nombre d'agneaux nés par fille et différences dans la note de carcasse selon les classes de fourrure

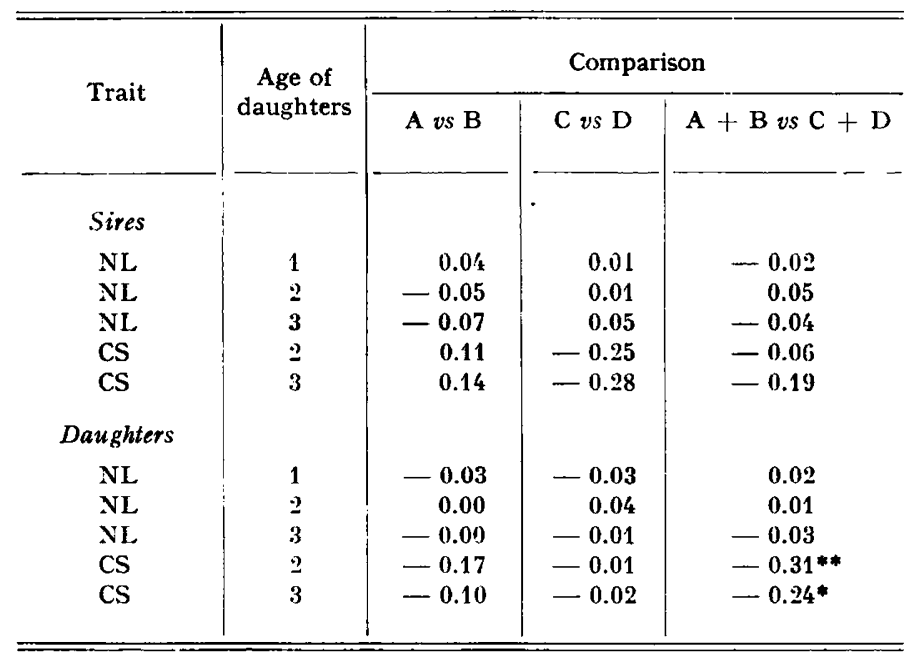


The effect of pelt class of sire on carcass score is in all cases non-significant. The results therefore show that there have been no marked differences between the sire groups under study with respect to their transmitting ability for fecundity and carcass score of daughters.

The tan daughter group $(\mathrm{C}+\mathrm{D})$, on the other hand, shows a significantly higher carcass score than the pure white daughter group $(\mathrm{A}+\mathrm{B})$ for both 2 and 3 year old daughters.

The discrepancy between pure white sires and pure white ewes in this respect indicates that the lowered carcass score of the pure white ewes is of incidental rather than causal nature. The increased selection intensity for pure white colour has lowered the selection intensity for live weight at weaning within ewe lambs in pelt classes $\mathrm{A}$ and $B$, as seen from tables 3 and 4 . It seems likely that the lowered carcass score of daughters in pelt classes $\mathrm{A}$ and $\mathrm{B}$ is a reflection of lowered selection intensity for carcass score of dams of these ewe lambs.

Reçu pour publication en novembre 1975.

\author{
RÉSUMÉ \\ INFLUENCE DES GÈNES \\ CONTROOLANT L'EXTENSION DE LA COULEUR ROUGE \\ SUR LA PRODUCTIVITE DU MOUTON ISLANDAIS
}

En race ovine Islandaise on a cherché à mesurer l'influence de la catégorie dans laquelle on peut ranger la fourrure des béliers et de leurs filles sur les performances d'agnelage des i 270 dites filles âgées de 1,2 et 3 ans et de 1023 filles âgées de 2 ou 3 ans. Il s'agissait des descendantes de I4I béliers.

L'échelle de notation comporte les catégories A : blanc pur avec une toison longue et homogène; $B$ : Blanc pur avec une toison de qualité moindre; $C$ : blanc avec des fibres rouges sur les bords de la toison; $\mathrm{D}$ : blanc avec des fibres rouges à l'intérieur de la toison.

Les filles des mâles des catégories A et B ont un poids au sevrage plus élevée que les filles des mâles des autres catégories. Les filles classées en $A$ et $B$ étaient plus légères au sevrage que celles des autres catégories. Cela était dâ à une sélection moins forte pour le poids au sevrage dans ces deux premières catégories.

La note de fourrure du père, pas plus que celle des filles, ne semble avoir d'effet sur les caractéristiques de fertilité des femelles.

Les filles notées A et $B$ ont des notes de carcasse plus faibles que les filles classées $C$ et $D$.

\title{
REFERENCES
}

Adalsteinsson S., 1966. Historical data on Iceland's sheep Industry. The National Wool Grower, 56 (II), IO-II.

Adalsteinsson S., I970. Colour inheritance in Icelandic sheep and relation between colour, fertility and fertilization. J. Agr. Res. Icel., 2, 3-135.

Adalsteinsson S., r97i a. Kynbótaeinkunn áa (Selection index for ewes). J. Agr. Res. Icel., 3, 28-38. (Icel., Engl, summary).

Adalsteinsson S., r97 r $b$. Garuflokkun og bungi á Islenskum lömbum (Pelt classification and live weight of Icelandic lambs). J. Agr. Res. Icel., 3, 34-39. (Icel., Engl. summary). 
Adazsteinsson S., 1975. Occurrence and inheritance of tan colour in Icelandic sheep. J. Agr. Res. Icel. 7, 55-62.

HARVey, Walter R., 1972. General outline of computing procedures for six types of mixed models. Dept. of Dairy Science, Ohio State University, Columbus, Ohio 43210. (Mimeographed).

Lauvergne J. J., I975. Génétique de la couleur de la toison de trois races ovines françaises Solognote, Bizet et Berrichonne. Ann. Génét. Sél. anim., 7, 263-276. 